\title{
22. DISTRIBUTION OF BROMINE, CI/Br RELATIONSHIPS, AND IODINE IN INTERSTITIAL WATER OF THE BLACK SEA, BASED ON DSDP LEG 42B
}

\author{
O.V. Shishkina, ${ }^{1}$ Institute of Oceanology, USSR \\ Academy of Sciences, Sadovaya, Lublino, Moscow
}

\section{INTRODUCTION}

The purpose of the present work was to study the distribution of bromine, chloride/bromide ratios, and iodine in interstitial waters of three holes in the Black Sea. The holes were drilled in the course of Leg 42B by D/V Glomar Challenger in May 1975.

Owing to their similar ionic radius, chloride and bromide ions resemble each other in chemical and geochemical behavior, occurrence, and migration patterns in the earth's crust. The larger ionic radius of iodine influences its pattern of dissemination and results in low Clarke values. Owing to their solubility, chloride and bromide are largely found in solution, principally in the sea and saline lakes.

Separation of chloride and bromide is achieved as a result of the greater solubility of bromide than chloride during the evaporation of seawater to the point of precipitation of $\mathrm{NaCl}$. Bromide remains in solution, being precipitated only at the very last stages of crystallization. The precipitate of $\mathrm{NaCl}$ contains only traces of $\mathrm{Br}$, whereas the residual liquid is enriched in bromide. Consequently, the $\mathrm{Cl} / \mathrm{Br}$ ratio diverges from its normal level of about 300 chiefly in two special cases: (1) as a result of volatilization of $\mathrm{NaCl}$, as occurs in meteorites, or leaching of salts having a $\mathrm{Cl} / \mathrm{Br}$ ratio greater than 300 ; (2) in waters mixed with residual brines rich in bromide with a $\mathrm{Cl} / \mathrm{Br}$ ratio less than 300 . Lesser separation occurs as a result of the differential sorptive properties, and the greater concentration of bromine in living matter. These processes lead to greater concentrations of bromine in soils, peat, clays enriched with organic matter, and interstitial waters.

$\mathrm{The} \mathrm{Cl} / \mathrm{Br}$ ratio in the seas and oceans equals 300 , or more precisely 293 . It remains constant (Vinogradov, 1948) in spite of introduction of river salts, coastal erosion, or even evaporation of fresh waters or seawater to the point of precipitation of $\mathrm{NaCl}$. Accordingly, deviations of $\mathrm{Cl} / \mathrm{Br}$ ratios from the norm serve as clues to the genesis of natural waters, and nature of interstitial processes.

As a result of the studies the enrichment of marine sediments in iodine was established, as well as the conditions under which iodine was transferred to pore waters. Iodine, along with other products, is enriched in interstitial waters in the course of breakdown of organic matter. The process is particularly prevalent in marine sediments in regions of high biological productivity. Iodine in such sediments is the source of

'Translated by F.T. Manheim. iodine of formation fluids, and has been used as a tracer element for potential presence of petroleum.

\section{METHODS}

Samples containing several $\mathrm{ml}$ of pore fluid were provided for the purpose of determining bromine and iodine. In samples from the highly mineralized sections of Holes 380/380A chlorine was redetermined argentometrically. For samples from Sites 379 and 381, shipboard values of chloride were used to calculate $\mathrm{Cl} / \mathrm{Br}$ ratios. These appear to be somewhat too high, but insufficient fluid was available to permit redeterminations. ${ }^{2}$ True chloride values are obtained by subtracting the sum of bromine and iodine from total halogens, with appropriate corrections for atomic weight.

Bromine was determined volumetrically, through oxidation by hypochlorite in acid medium, followed by iodometric titration. The method gives the sum of bromine and iodine. Corrected bromine is obtained by subtracting iodine with correction for atomic weight. For calculating $\mathrm{Cl} / \mathrm{Br}$ ratios data are taken in units of $\mathrm{g} / \mathrm{kg}(\%)$.

Iodine is determined by the volumetric method, after separation of organic matter, by oxidation with bromine water and subsequent iodometric titration (Shishkina et al., 1969). In a number of instances the more sensitive method of Miller and Schneider (1963) was employed. Data are given in $\mathrm{mg} / \mathrm{kg}$.

All analyses were performed by G.A. Pavlova and V.S. Bykova under the supervision of the author. Results are shown in Tables 1 to 4 and in Figures 1 to 3.

\section{DISCUSSION OF RESULTS}

Site 379 is located in the eastern central basin of the Black Sea, where the surficial layer of sediments is enriched in organic matter (Shishkina, 1959, 1962). Interstitial chloride, salinity, alkalinity, calcium, and magnesium reveal the history of development of the Black Sea basin and diagenetic interactions between the sediments and waters.

In Hole 379A, at 3.94 meters depth, the interstitial waters already show a lower chlorinity and salinity than Black Sea bottom water $(11.44 \%$ and $20.20 \%$ respectively). With depth, chlorinity drops to $2.7 \%$ at

\footnotetext{
${ }^{2}$ Translator's note: The shipboard data of Manheim and Sotelo are given in $\mathrm{g} / \mathrm{l}$, not $\mathrm{g} / \mathrm{kg}$ as assumed by Shishkina. This makes the chloride values appear too high, as the author notes. The data cited by Shishkina have therefore been replaced by either laboratory data, or shipboard values corrected for specific gravity, as noted. $\mathrm{Cl} / \mathrm{Br}$ ratios have been recalculated wherever the "USA" data were used
} 
TABLE 1

Chloride, Bromide, and $\mathrm{Cl} / \mathrm{Br}$ for Interstitial Waters at Site 379

\begin{tabular}{lcccccc}
\hline $\begin{array}{l}\text { Sample } \\
\text { (USA) }\end{array}$ & $\begin{array}{c}\text { Sample } \\
\text { (Interval in cm) }\end{array}$ & $\begin{array}{c}\mathrm{Cl} \\
(\% \circ)\end{array}$ & $\begin{array}{c}\mathrm{Br} \\
\mathrm{USA}^{\mathrm{a}}\end{array}$ & $\begin{array}{c}\mathrm{I} \\
(\%)\end{array}$ & $\begin{array}{c}\text { Depth } \\
(\mathrm{m})\end{array}$ \\
\hline
\end{tabular}

Hole 379A

$\begin{array}{rrrrrrr}1 & 1-3,144-150 & 11.44 & 0.039 & 293 & 2.10 & 3.94 \\ 2 & 4-3,144-150 & 2.65 & 0.013 & 204 & 8.81 & 32.44 \\ 3 & 7-3,140-150 & 3.28 & 0.016 & 205 & 12.26 & 60.9 \\ 4 & 12-2,140-150 & 3.24 & 0.020 & 162 & 12.79 & 110.3 \\ 6 & 19-5,140-150 & 2.00 & 0.018 & 111 & 18.40 & 166.9 \\ 7 & 21-5,140-150 & 1.96 & 0.019 & 103 & 19.54 & 185.9 \\ 8 & 23-5,137-150 & 1.75 & 0.018 & 97 & 19.54 & 204.9 \\ 11 & 29-4,140-150 & 3.00 & 0.021 & 142 & 19.72 & 268.4 \\ 13 & 34-5,140-150 & 3.67 & 0.026 & 141 & 21.75 & 318.9 \\ 14 & 36-3,140-150 & 4.15 & 0.025 & 166 & 24.27 & 336.4 \\ 16 & 40-3,140-150 & 3.62 & 0.033 & 110 & 26.65 & 372.9 \\ 17 & 43-2,140-150 & 5.19 & 0.035 & 148 & 28.32 & 380.9 \\ 18 & 45-2,140-150 & 5.92 & 0.041 & 144 & 30.49 & 399.9 \\ 19 & 47-3,140-150 & 7.42 & 0.046 & 161 & 32.96 & 429.9 \\ 27 & 64-4,128-138 & 19.71 & 0.099 & 199 & 41.60 & 583.2\end{array}$

Hole 379B

\begin{tabular}{rrrrrrr}
2 & $3-1,145-150$ & $3.03^{\mathrm{b}}$ & 0.015 & 202 & 8.21 & 17.5 \\
3 & $4-1,140-150$ & $3.43^{\mathrm{b}}$ & 0.013 & 264 & 12.00 & 50.0 \\
5 & $5-2,144-150$ & $3.30^{\mathrm{c}}$ & 0.017 & 194 & 14.03 & 81.0 \\
\hline
\end{tabular}

a Data of Manheim and Schug (this volume).

b Shipboard data in grams per liter.

${ }^{c}$ Chloride determined argentometrically by author.

TABLE 2

Chloride, Bromide, and $\mathrm{Cl} / \mathrm{Br}$ for Interstitial Waters in Hole 380

\begin{tabular}{|c|c|c|c|c|c|c|c|}
\hline $\begin{array}{l}\text { Sample } \\
\text { (USA) }\end{array}$ & $\begin{array}{c}\text { Sample } \\
\text { (Interval in cm) }\end{array}$ & $\begin{array}{c}\mathrm{Cl} \\
(\% \circ) \\
\mathrm{USA}^{\mathrm{a}}\end{array}$ & $\begin{array}{l}\mathrm{Cl} \\
(\% \circ) \\
\text { SSSR }\end{array}$ & $\begin{array}{c}\mathrm{Br} \\
(\%)\end{array}$ & $\mathrm{Cl} / \mathrm{Br}$ & $\underset{(\mathrm{mg} / \mathrm{kg})}{\mathrm{I}}$ & $\begin{array}{l}\text { Depth } \\
\text { (m) }\end{array}$ \\
\hline 38 & $1-5,140-150$ & $9.63^{b}$ & 9.26 & 0.028 & 331 & 5.52 & 7.9 \\
\hline 40 & $6-3,140-150$ & 16.7 & 17.03 & 0.042 & 405 & 19.63 & 55.4 \\
\hline 42 & $10-3,140-151$ & 20.3 & 21.61 & 0.059 & 366 & 18.97 & 92.0 \\
\hline 44 & $14-5,140-150$ & 25.0 & - & 0.045 & 555 & 42.93 & 133.5 \\
\hline 48 & $21-3,140-150$ & 27.2 & 26.86 & 0.059 & 455 & 25.24 & 194.9 \\
\hline $50^{\mathrm{c}}$ & $25-3,140-150$ & - & 23.11 & 0.048 & 481 & 17.25 & 232.8 \\
\hline 52 & $29-1,140-150$ & 33.1 & - & 0.081 & 409 & 25.11 & 273.9 \\
\hline
\end{tabular}

a Data of Manheim and Schug (this volume).

bShipboard data corrected for specific gravity $(\mathrm{g} / \mathrm{kg})$.

'Probably contaminated (translator's note).

32.4 meters and maintains low salinities to 268 meters depth, fluctuating between 1.8 and $3.3 \%$. Low chlorinity and correspondingly low salinity characterize freshening of the basin during the Neoeuxinian epoch, when it was isolated from the Mediterranean Sea. At this time the sea was also aerated from top to bottom, as indicated by the positive sediment redox potentials at core depths of 6-8 meters from the sea floor (Shishkina, 1961). Further corroboration is provided by studies of sulfur isotopes (Vinogradov et al., 1962).

From 268 to 621 meters chlorinity gradually increases to values exceeding those in the modern oceans, $20.92 \%$ (Table 1, Figure 1). The more saline fluids in the interval 268 to 621 meters provide the concentration gradients for upward diffusion of salts in the section.

The distribution of bromine in pore waters in Hole $379 \mathrm{~A}$ follows closely that of chloride. In the uppermost sediment absolute concentration of bromide in interstitial waters is $0.039 \%$ and the $\mathrm{Cl} / \mathrm{Br}$ ratio is
TABLE 3

Chloride, Bromide, and $\mathrm{Cl} / \mathrm{Br}$ for Interstitial Waters in Hole $380 \mathrm{~A}$

\begin{tabular}{lccccccc}
\hline $\begin{array}{l}\text { Sample } \\
\text { (USA) }\end{array}$ & $\begin{array}{c}\text { Sample } \\
\text { (Interval in cm) }\end{array}$ & $\begin{array}{c}(\% \circ) \\
\text { USA }\end{array}$ & $\begin{array}{c}(\% \%) \\
\text { SSSR }\end{array}$ & $\begin{array}{c}\mathrm{Br} \\
(\%)\end{array}$ & $\begin{array}{c}\mathrm{Cl} / \mathrm{Br} \\
(\mathrm{mg} / \mathrm{kg})\end{array}$ & $\begin{array}{c}\text { Depth } \\
(\mathrm{m})\end{array}$ \\
\hline 58 & $1-2,140-150$ & 37.5 & 37.36 & - & - & - & 336 \\
59 & $5-4,140-150$ & 38.4 & 38.32 & 0.072 & 532 & 27.96 & 376.9 \\
60 & $7-2,0-10$ & 39.8 & 40.33 & 0.074 & 544 & - & 406.9 \\
62 & $11-4,140-150$ & 42.5 & 41.57 & 0.061 & 681 & 31.52 & 434.9 \\
63 & $13-1,140-150$ & 39.9 & 40.46 & 0.094 & 430 & 27.41 & 450 \\
64 & $15-7,140-150$ & 41.1 & 40.73 & - & - & 28.61 & 475 \\
65 & $17-5,140-150$ & 41.1 & 41.31 & 0.074 & 558 & 27.22 & 490.9 \\
68 & $23-5,140-150$ & 42.2 & 42.69 & 0.069 & 619 & 30.31 & 549.9 \\
71 & $29-5,140-150$ & 43.7 & 43.63 & 0.082 & 532 & 28.12 & 598.5 \\
73 & $33-2,140-150$ & - & 44.06 & 0.069 & 638 & 28.93 & 630.5 \\
74 & $36-4,140-150$ & 43.8 & 44.04 & - & - & - & 652.5 \\
76 & $43-5,0-15$ & 48.5 & 48.40 & 0.080 & 605 & 27.80 & 728.5 \\
77 & $46-5,140-150$ & 47.7 & 50.12 & 0.101 & 496 & 29.25 & 758.4 \\
78 & $49-5,135-150$ & 50.6 & 50.43 & - & - & - & 787.0 \\
79 & $52-2,000-015$ & 50.6 & 52.48 & 0.095 & 552 & 28.84 & 810.2 \\
82 & $63-2,140-150$ & 55.0 & 55.18 & 0.105 & 526 & 27.95 & 918.4 \\
87 & $73-3,130-150$ & 57.3 & 57.88 & - & - & - & 1014.3 \\
\hline
\end{tabular}

a Data of Manheim and Schug (this volume).

${ }^{\mathrm{b}}$ Shipboard data correcred for specific gravity $(\mathrm{g} / \mathrm{kg})$.

TABLE 4

Chloride, Bromide, and $\mathrm{Cl} / \mathrm{Br}$ for Interstitial Waters at Site 381

\begin{tabular}{ccccccr}
\hline $\begin{array}{c}\text { Sample } \\
\text { (USA) }\end{array}$ & $\begin{array}{c}\text { Sample } \\
\text { (Interval in cm) }\end{array}$ & $\begin{array}{c}\mathrm{Cl} \\
(\%)\end{array}$ & $\begin{array}{c}\mathrm{Br} \\
\mathrm{USA}^{\mathrm{a}}\end{array}$ & $\begin{array}{c}\mathrm{Br} \\
(\%)\end{array}$ & $\begin{array}{c}\mathrm{Cl} / \mathrm{Br} \\
(\mathrm{mg} / \mathrm{kg})\end{array}$ & $\begin{array}{c}\text { Depth } \\
(\mathrm{m})\end{array}$ \\
\hline 91 & $1-2,144-150$ & 15.7 & 0.042 & 374 & 5.86 & 3.00 \\
92 & $2-2,145-150$ & 16.2 & 0.055 & 295 & 7.81 & 17.40 \\
93 & $3-3,140-150$ & 23.5 & 0.081 & 290 & 15.65 & 27.00 \\
95 & $7-5,140-150$ & 36.0 & 0.090 & 400 & 26.65 & 65.00 \\
97 & $12-4,140-150$ & $30.2^{\mathrm{b}}$ & 0.109 & 277 & 20.80 & 111.00 \\
98 & $14-5,135-150$ & $35.6^{\mathrm{b}}$ & 0.119 & 299 & 27.41 & 133.00 \\
100 & $16-5,135-150$ & 37.7 & 0.117 & 322 & 26.42 & 152.00 \\
103 & $23-1($ top) & 37.7 & 0.110 & 342 & 26.42 & 209.00 \\
104 & $25-3,140-150$ & 37.7 & 0.131 & 288 & 29.28 & 225.00 \\
105 & $27-2,140-150$ & 38.4 & 0.113 & 340 & 29.30 & 244.00 \\
106 & $29-5,000-15$ & 39.5 & 0.103 & 383 & 29.65 & 264.50 \\
107 & $31-4,140-150$ & 39.4 & 0.126 & 312 & 30.20 & 282.00 \\
108 & $33-4,140-150$ & 38.7 & 0.111 & 349 & 29.41 & 301.00 \\
109 & $35-5,140-150$ & 39.4 & 0.154 & 256 & 32.68 & 321.50 \\
110 & $37-2,140-150$ & 40.1 & 0.113 & 355 & 30.45 & 336.00 \\
\hline
\end{tabular}

a Data of Manheim and Schug (this volume).

b Shipboard data corrected for specific gravity $(\mathrm{g} / \mathrm{kg})$.

293 , similar to that in normal seawater $(293 \pm 3)$. With depth the absolute concentration of bromide decreases with the general freshening of the section, but the $\mathrm{Cl} / \mathrm{Br}$ ratio decreases sharply and fluctuates between 97 and 205 meters. Below 336.4 meters the concentration of bromide increases in absolute terms and the $\mathrm{Cl} / \mathrm{Br}$ ratio fluctuates between 100 and 199 , significantly lower than normal values for ocean waters $(\mathrm{Cl} / \mathrm{Br}=300)$. The source of chloride and bromide in pore fluids at depths below 600 meters appears to be brines formed through evaporation of seawater up to the stage of precipitation of $\mathrm{NaCl}$, i.e., relatively richer in bromide than chloride. This is suggested by the significant lowering of the $\mathrm{Cl} / \mathrm{Br}$ ratio in the pore fluids of the site. Fluctuation of $\mathrm{Cl} / \mathrm{Br}$ ratios from layer to layer may be explained by variable rates of diffusion for ions of the elements in question and varying sediment properties with depth, such as permeability, water content, etc.

The enrichment of bromide and the significant enrichment of iodine in the pore fluids attests to the the process of mineralization of organic matter, but for bromide this factor plays a lesser role than brine as a source. 

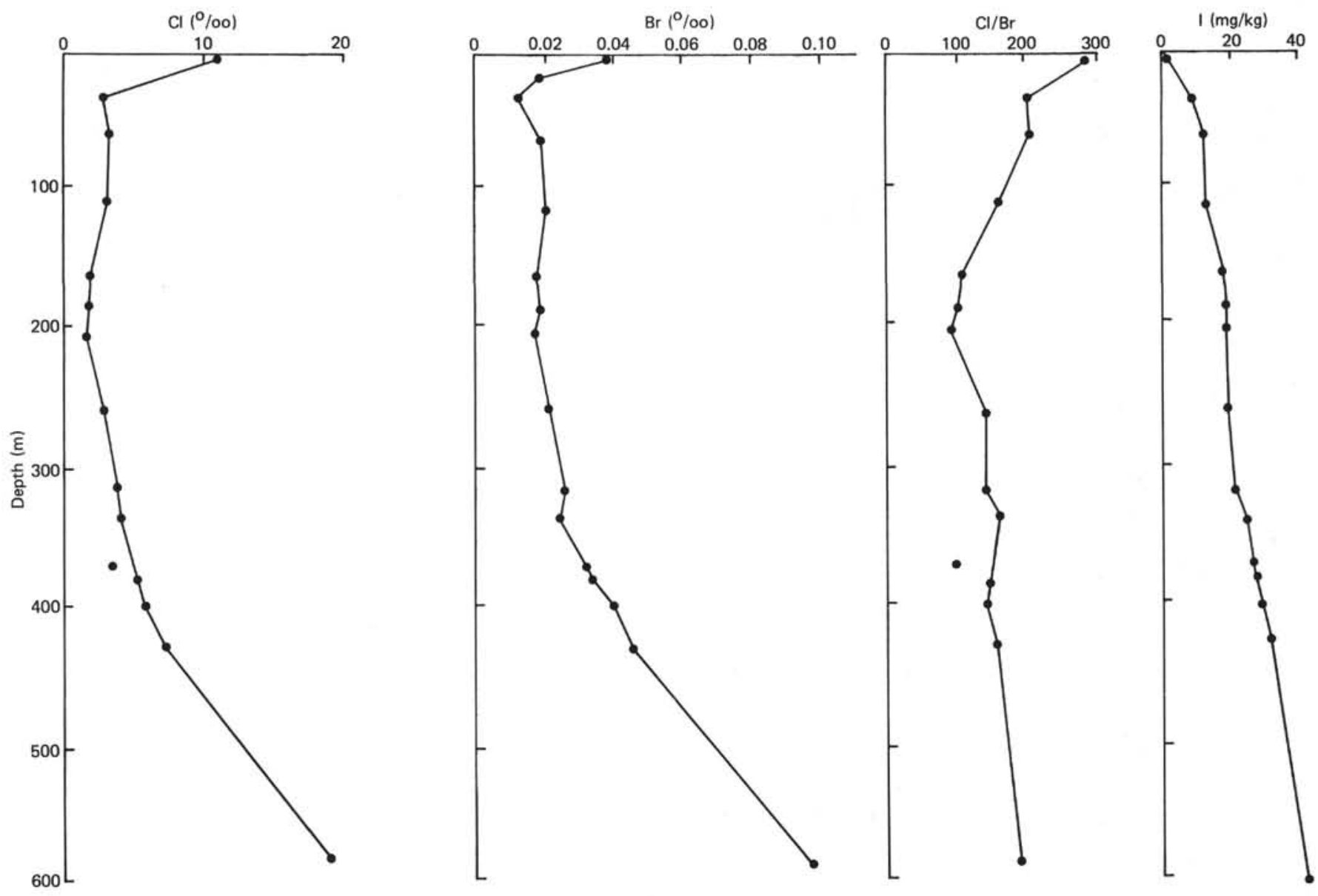

Figure 1. Distribution of $\mathrm{Cl}, \mathrm{Br}, \mathrm{Cl} / \mathrm{Br}$, and I in Sites $379 \mathrm{~A} / \mathrm{B}$.

Accumulation of iodine in the pore fluids of Site 379 is intensive. The iodine concentration in pore fluids of the uppermost horizon of sediments $(2.1 \mathrm{mg} / \mathrm{kg})$ is already 50 times greater than in seawater. Iodine further increases consistently with depth and reaches $41.6 \mathrm{mg} / \mathrm{kg}$ at 583.2 meters. Such enrichment in pore waters of the Black Sea, peripheral areas of the Pacific Ocean (off Peru, Chile, Japan) and in the Atlantic Ocean off Southwest Africa may be attributed to mineralization of sediments rich in reactive organic matter. Such mineralization causes increases in concentrations of iodine, ammonia, alkalinity, and other properties (Pavlova and Shishkina, 1973). Pore waters having large iodine concentrations are usually in the process of, or have undergone, major diagenetic transformations, and become chloride-alkaline waters lacking in sulfate (in continental margin areas) or chloride-calcium waters (in the Black Sea).

Interstitial waters found in the course of drilling Site 379 represent chloride-calcium waters of various concentrations. The process of consolidation of sediments with depth and increasing temperature (to $32^{\circ} \mathrm{C}$ ) contributes to the process of iodine enrichment in pore fluids. In general, these processes, including enrichment in iodine, bromine, and ammonia are analogous to those observed in corresponding types of formation fluids found in oilfield basins.

At Site 380, in the Bosporus region, interstitial waters were obtained from two columns: Hole 380 ( 7.9 to 360 $\mathrm{m}$ ) and Hole 380A (336 to $1068 \mathrm{~m}$ ). Pore waters of low salinity, corresponding to the fresh-water stage of the Black Sea were obtained at 7.9 meters, where a chlorinity of $9.26 \%$ was obtained (Tables 2 and 3, Figure 2). The nature and changes in pore fluid in the uppermost strata of sediment (to 10-12 m depth) delineates the fresh-water stage of the basin, known from our previous work (Shishkina, 1967, 1972).

A major feature of interest in this site is the increase in chlorinity salinity with depth; the latter reaches 98 $\%$ at 1050 meters, or three times greater than the salt content of present-day seawater. Its ionic composition also changes.

Study of bromide and $\mathrm{Cl} / \mathrm{Br}$ ratio in this site is especially significant, in that it provides an answer to the question of the source of the brines and mechanism of their emplacement, while elaborating information on the history of development of the Black Sea basin.

Greater increase in chloride concentration than bromide with depth is indicated by $\mathrm{Cl} / \mathrm{Br}$ ratios having values greater than 300 . The ratios fluctuate in most cases around 500, with some isolated horizons having ratios of 600 and higher (681; Sample 62, Hole 380A). The absolute concentrations of chloride increase gradually and evenly with depth, following the diffusion laws, and providing an indication of the lack of reactivity of chloride in sediment-water systems. In contrast, bromide fluctuates, presumably in response to mineralization of organic matter, and perhaps also in 

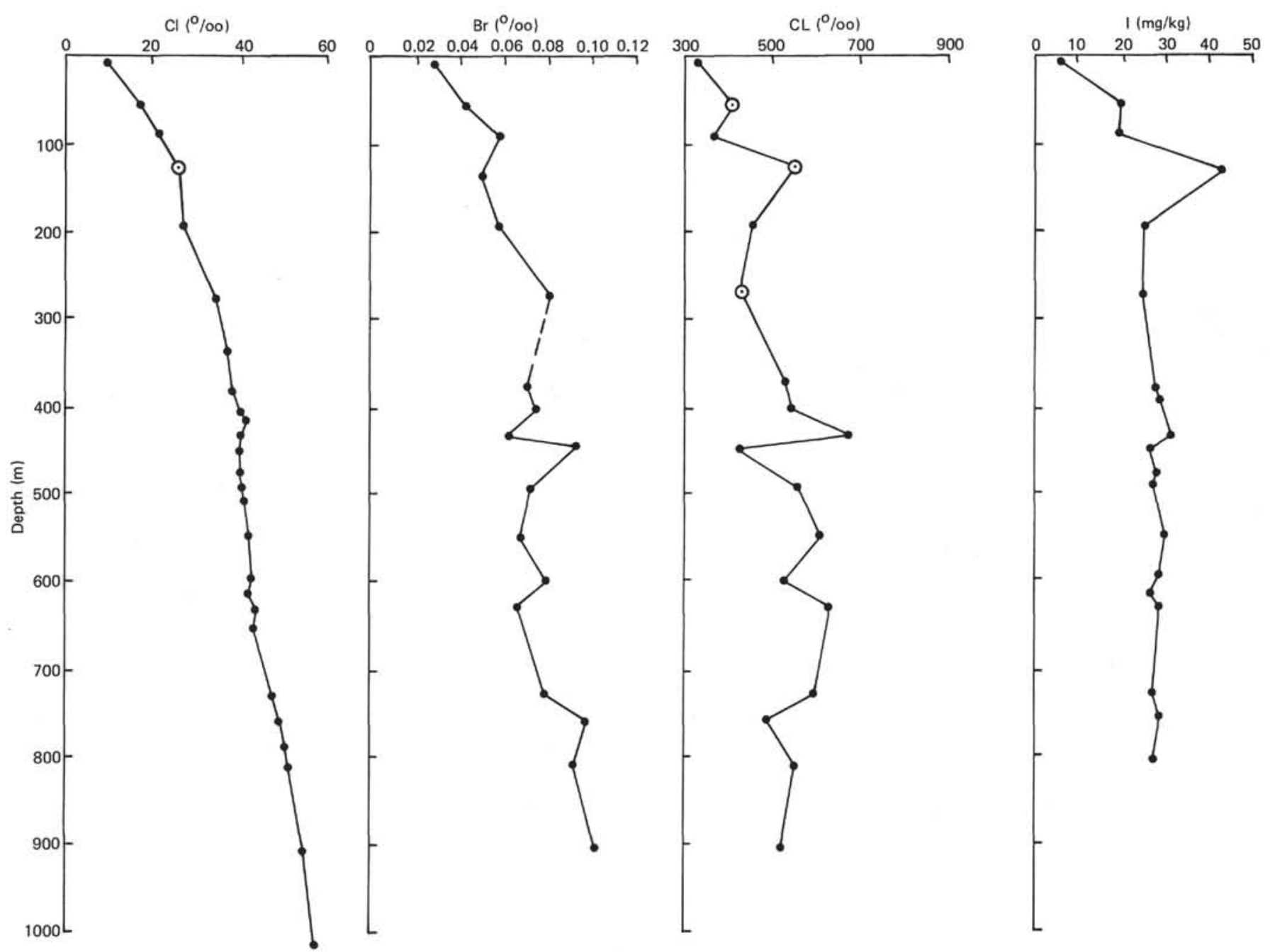

Figure 2. Distribution of $\mathrm{Cl}, \mathrm{Br}, \mathrm{Cl} / \mathrm{Br}$, and I in Holes 380/380A.
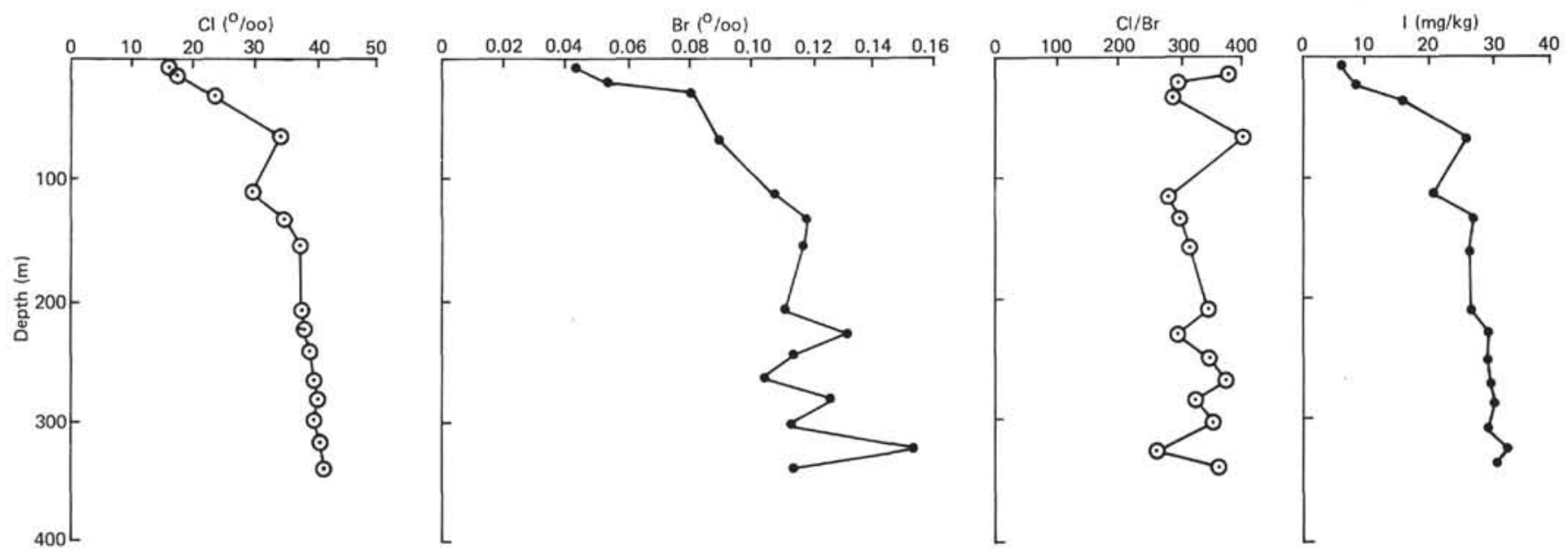

Figure 3. Distribution of $\mathrm{Cl}, \mathrm{Br}, \mathrm{Cl} / \mathrm{Br}$, and I in Site 381.

response to varying diffusional conditions. The key feature is that the $\mathrm{Cl} / \mathrm{Br}$ ratio is well above 300 . This indicates that the pore fluids are influenced by waters that have leached salt deposits, or by deeper pore fluids (not reached by the drill) that have leached salt layers. Data on dolomite and other minerals in the cores confirm the existence of an evaporite basin. The data on the $\mathrm{Cl} / \mathrm{Br}$ ratios indicate that evaporation reached the stage of halite precipitation. Leaching of halite produces waters having high concentrations of chloride but low concentrations of bromide.

Iodine concentrations in the pore waters increase with depth from $5.52 \mathrm{mg} / \mathrm{kg}$ at 7.9 meters to 42.9 $\mathrm{mg} / \mathrm{kg}$ at 133.5 meters depth. Within the upper 300 
meters iodine concentrations fluctuate from horizon to horizon within the limits of 17.25 to $42.9 \mathrm{mg} / \mathrm{kg}$. In deeper layers concentrations remain relatively constant at $28-31 \mathrm{mg} / \mathrm{kg}$. Accumulation processes for this element have been described previously.

At Site 381 , drilled near Site 380 in the Bosporus region, the upper sediment layers containing freshwater sequences are absent. Pore fluids at a depth of 3 meters already show chlorinity of $15.7 \%$, appreciably higher than the chlorinity of near-bottom waters of the Black Sea. With greater depth interstitial salinities increase to $40.1 \%$ at 336 meters (Table 4, Figure 3). The concentration of bromide also increases with depth, but the $\mathrm{Cl} / \mathrm{Br}$ ratio fluctuates around values not far from 300, which is noteworthy considering the increase in total chlorinity. Local decreases in $\mathrm{Cl} / \mathrm{Br}$ ratios below 300 may be attributed to liberation of bromide in the course of mineralization of organic matter at specific horizons. Comparison of data on the distribution of chloride and bromide and $\mathrm{Cl} / \mathrm{Br}$ between Holes $380 / 380 \mathrm{~A}$ and 381 shows the appreciably less, if any, influence on the latter of waters that may have leached salt deposits.

At Site 381 the distribution of $\mathrm{Cl} / \mathrm{Br}$ in the pore fluids does not give as clear a picture as in the preceding sites. One must also note that varying rates of sedimentation, and consequent differences in age of the deposits and time available for diffusion, lead to differences in the distribution of elements in pore waters at different depths. Distribution of iodine in pore fluids is similar to that observed at Holes $380 / 380 \mathrm{~A}$. Its concentration increases from $5.86 \mathrm{mg} / \mathrm{kg}$ at 3 meters to $32.68 \mathrm{mg} / \mathrm{kg}$ at 321.5 meters, and in general, is governed by previously discussed mechanisms.

\section{CONCLUSIONS}

1. The results of studies of bromide concentrations and $\mathrm{Cl} / \mathrm{Br}$ ratios in interstitial waters show as principal features $\mathrm{Cl} / \mathrm{Br}$ ratios $<300$ at Holes 379/379A, and $\mathrm{Cl} / \mathrm{Br}>300$ at Holes $380 / 380 \mathrm{~A}$ and 381 in the peripheral parts of the Black Sea.

These data provide information on the sources and mechanisms of distribution of chloride and bromide in the pore fluids. At Holes 379A/B increased concentrations of chloride and bromide at depths to 600 meters below sea floor, and relative enrichment in bromine are associated with hypersaline brines. These formed as a result of evaporation of seawater in basins reaching the stage of deposition of $\mathrm{NaCl}$.

At Holes $380 / 380 \mathrm{~A}$ pore waters are more strongly enriched in chloride than in bromide, as indicated by $\mathrm{Cl} / \mathrm{Br}$ ratios in the range of 500 to 600 . This indicates influence of waters (possibly deeper lying waters) that may have leached deposits of solid $\mathrm{NaCl}$. The remaining distribution of the elements in question are explained by upward diffusion of salts.

2. Pore waters of all three holes are enriched in iodine. Its concentration ranges from 2 to $5 \mathrm{mg} / \mathrm{kg}$ to $41.6 \mathrm{mg} / \mathrm{kg}$ in Hole $379 \mathrm{~A}$, to $28.8 \mathrm{mg} / \mathrm{kg}$ at 810 meters depth in Hole $380 \mathrm{~A}$ and to $30.45 \mathrm{mg} / \mathrm{kg}$ at 336 meters at Site 381. Accumulation of iodine in interstitial waters occurs as a result of mineralization of organic matter and simultaneous liberation of other products of decomposition (ammonia). The large concentrations of iodine in pore waters of Hole $379 \mathrm{~A}$ are explained by the deposition of these sediments in the region of "halistasis" or high organic enrichment. As a result of diagenesis and consolidation, iodine is transferred from the sediment to the pore fluid. This process is facilitated by higher temperatures to $32^{\circ}-40^{\circ} \mathrm{C}$ in the deeper layers. Concentration of iodine in pore waters in the range 30 to $40 \mathrm{mg} / \mathrm{kg}$ is comparable to the range in oil field brines. Observation of iodine at such concentrations may be used as an exploration tool for oil prospecting.

\section{REFERENCES}

Miller, A.D. and Schneider, L.A., 1963. Opredelenie mikrokolichestv ioda v prirodnykh vodakh kataliticheskim metodom (Determination of microquantities of iodine in natural waters by the catalytic method): Zh. Analit. Khimiya, v. 18, no. 3.

Pavlova, G.A. and Shishkina, O.V., 1973. Raspredelenie ioda $\mathrm{v}$ osadkakh Tikhogo okeana $\mathrm{i}$ nakoplenie ego $\mathrm{v}$ ilovykh vodakh $\mathrm{v}$ protesse ikh metamorfizatsii (Distribution of iodine in sediments of the Pacific Ocean and accumulation in pore waters as a result of their metamorphism): Geokhimiya, no. 7.

Shishkina, O.V., 1959. Metamorfizatsiya khimicheskogo sostava ilovykh vod Chernogo morya. Soobschenie I. Sb. "K poznaniyu diageneza morskikh osadkov", (Metamorphism of the chemical composition of pore waters of the Black Sea). In Strakhov, N.M. (Ed.), Toward understanding diagenesis of marine sediments: Izdatel'stvo Akad. Nauk, SSSR, Moscow.

1961. Okislitel'no-vosstanovitel'nyi potentsial verkhnei desyatimetrovoi tolschi Chetyertichnykh otlozhenii Chernogo morya (Oxidation-reduction potential in the upper $10 \mathrm{~m}$ sediment layers of the Black Sea): Doklady Akad. Nauk, SSSR, v. 139, no. 5. 1962. Nekotorye rezultaty issledovaniya ilovykh vod Cherno morya (Some results of studies of pore fluids in the Black Sea): Trudy Institute of Oceanology, Akad. Nauk, SSSR, v. 54, contrib. 2.

1967. Otlichitel'nyei cherty khimicheskogo sostava ilovykh vod Chernogo morya (Special features of chemical composition of pore fluids in the Black Sea). In Geofizicheksie i Gidrokhimicheskie Issledovaniya v Chernom more: Izatel'stvo "Nauka," Moscow.

1972. Geokhimiya morskikh i okeanicheskikh ilovykh vod (Geochemistry of marine and oceanic pore fluids): Izdatel'stvo "Nauka," Moscow.

Shishkina, O.V., Pavlova, G.A., and Bykova, V.S., 1969. Geokhimiya galogenov v morskikh okeanskikh osadkakh $i$ ilovykh vodakh (Geochemistry of halogens in marine sediments and pore waters): Izdatel'stvo "Nauka," Moscow.

Vinogradov, A.P., 1948. Rasseyannye khimicheskie elementy $\mathrm{v}$ podzemnykh vodakh raznogo proiskhozhdeniya (Distribution of chemical elements in underground waters of various origin): Trudy Lab. Gidrogeol. Probelm. Akad. Nauk, SSSR, v. 1.

Vinogradov, A.P., Grinenko, V.A., and Ustinov, V.I., 1962. Izotopnyi sostav soedinenii sery v Chernom More (Isotopic composition of sulfur compounds in the Black Sea): Geokhimiya, no. 10. 